\title{
Author Correction: Bone morphogenetic protein 7 promotes resistance to immunotherapy
}

Maria Angelica Cortez (1D, Fatemeh Masrorpour, Cristina Ivan (D), Jie Zhang, Ahmed I. Younes (D), Yue Lu, Marcos R. Estecio, Hampartsoum B. Barsoumian, Hari Menon, Mauricio da Silva Caetano, Rishab Ramapriyan (D), Jonathan E. Schoenhals, Xiaohong Wang, Ferdinandos Skoulidis, Mark D. Wasley, George Calin (1), Patrick Hwu \& James W. Welsh

Correction to: Nature Communications https://doi.org/10.1038/s41467-020-18617-z, published online 24 September 2020.

The original version of this Article contained an error in the spelling of the author Ahmed I. Younes, which was incorrectly given as Ahmed Younes. This has now been corrected in both the PDF and HTML versions of the Article.

Published online: 08 October 2020

\footnotetext{
(c) (i) Open Access This article is licensed under a Creative Commons Attribution 4.0 International License, which permits use, sharing, adaptation, distribution and reproduction in any medium or format, as long as you give appropriate credit to the original author(s) and the source, provide a link to the Creative Commons license, and indicate if changes were made. The images or other third party material in this article are included in the article's Creative Commons license, unless indicated otherwise in a credit line to the material. If material is not included in the article's Creative Commons license and your intended use is not permitted by statutory regulation or exceeds the permitted use, you will need to obtain permission directly from the copyright holder. To view a copy of this license, visit http://creativecommons.org/licenses/by/4.0/.
}

(c) The Author(s) 2020 